\title{
Tectonic implications of felsic tuffs within the Lower Miocene Gangrinboche conglomerates, southern Tibet
}

\author{
Jonathan C. Aitchison ${ }^{\mathrm{a}, *}$, Jason R. Ali ${ }^{\mathrm{a}}$, Angel Chan ${ }^{\mathrm{a}}$, Aileen M. Davis ${ }^{\mathrm{a}}$, Ching-Hua Lo ${ }^{\mathrm{b}}$ \\ a Tibet Research Group, Department of Earth Sciences, University of Hong Kong, Pokfulam Road, Hong Kong SAR, China \\ ${ }^{\mathrm{b}}$ Department of Geosciences, National Taiwan University, Taipei, Taiwan
}

\section{A R T I C L E I N F O}

\section{Article history:}

Received 7 January 2008

Received in revised form 30 April 2008

Accepted 19 May 2008

\section{Keywords:}

Tibet

Miocene

Collision

Dacite

Adakite

Molasse

Slab break-off

\begin{abstract}
A B S T R A C T
Felsic tuffs are interbedded with the Gangrinboche conglomerates adjacent to the Yarlung Tsangpo suture zone in southern Tibet. Laser Ar/Ar dating of mineral separates indicates they are of Early Miocene age. Such tuffs are most likely an eruptive manifestation of geochemically indistinguishable coeval felsic (adakitic) intrusions that are widely reported across southern Tibet. The considerable lateral (E-W) extent of the Gangrinboche conglomerates and their depositional setting indicates sediment accumulation in an overall $\mathrm{N}-\mathrm{S}$ compressional regime and thereby places important constraints on the tectonic setting in which magmatism initiated. The conglomerates were folded and truncated during back-thrusting associated with development of the north-directed Great Counter thrust. As N-S trending rifts associated with E-W extension of the Tibetan Plateau cut both the conglomerates and this thrust system it can be inferred that post-collisional volcanism is unlikely to have been genetically linked to later E-W extension. Early Miocene slab break-off beneath Tibet provides a model that appears to be consistent with petrogenesis of the associated magmatic suite, which requires a lowermost crust or lithospheric mantle generation, molasse accumulation, and uplift and emplacement of North Himalayan gneiss domes.
\end{abstract}

(ㄷ) 2008 Elsevier Ltd. All rights reserved.

\section{Introduction}

Distinctive post-collisional igneous rocks of calc-alkaline affinity are a widespread Miocene feature across southern Tibet (Fig. 1). They typically occur as dikes and porphyry intrusions along, and to the north of, the Yarlung Tsangpo suture zone (YTSZ) (Turner et al., 1993, 1996; Chung et al., 1998, 2003, 2005; Williams et al., 2001, 2004; Hou et al., 2004; Nomade et al., 2004; Gao et al., 2007). Such rocks are generally interpreted within the context of existing numerically constrained, but mutually exclusive, hypotheses developed to explain evolution of the Tibet-Himalaya orogenic system. One model explains rapid uplift of the Tibetan Plateau (Harrison et al., 1992) by invoking delamination of a large lithospheric root (England and Houseman, 1989; Houseman and England, 1996). An alternative model links uplift and development of the Greater Himalayan sequence, together with a series of gneissic domes that crop out north of the Himalaya, to a process whereby a crustal channel flow occurs under Tibet in response to topographic gradients and high rates of erosional denudation at the Himalayan front resulting from continental collision. Melt channelled from beneath the Lhasa terrane passes in a south-directed ductile flow, at mid-crustal levels, beneath the YTSZ to south-

\footnotetext{
* Corresponding author. Tel.: +852 28598047; fax: +852 25176912.

E-mail address: jona@hku.hk (J.C. Aitchison).
}

ern Tibet and the Greater Himalaya where rocks so produced locally reach the surface (Beaumont et al., 2001, 2004; Jamieson et al., 2004).

Although rocks on the Tibetan Plateau are commonly well exposed their relative inaccessibility necessarily results in models being based on limited data sets. As these models are developed from the largest active orogenic system on Earth they are now widely applied to explain phenomena in other fossil orogens (e.g. Collins, 1994; St-Onge et al., 2006). Thus, it is useful if any improved understanding of Early Miocene Tibet can be applied to better constrain the tectonic evolution of this region and test existing models. We report on the first discovery of tuffs associated with Miocene magmatic activity across southern Tibet. Knowledge of the depositional setting into which the pyroclastic material was erupted imposes significant first-order geological constraints on the tectonic development of this region and allows testing of existing hypotheses.

\section{Gangrinboche conglomerates}

A narrow elongate zone of molasse, the Gangrinboche conglomerates (GC), crops out across Tibet along the northern margin of the YTSZ. These sedimentary rocks were described in detail by Aitchison et al. (2002). Correlative strata along strike crop out further west in NW India where they are referred to as the Indus 


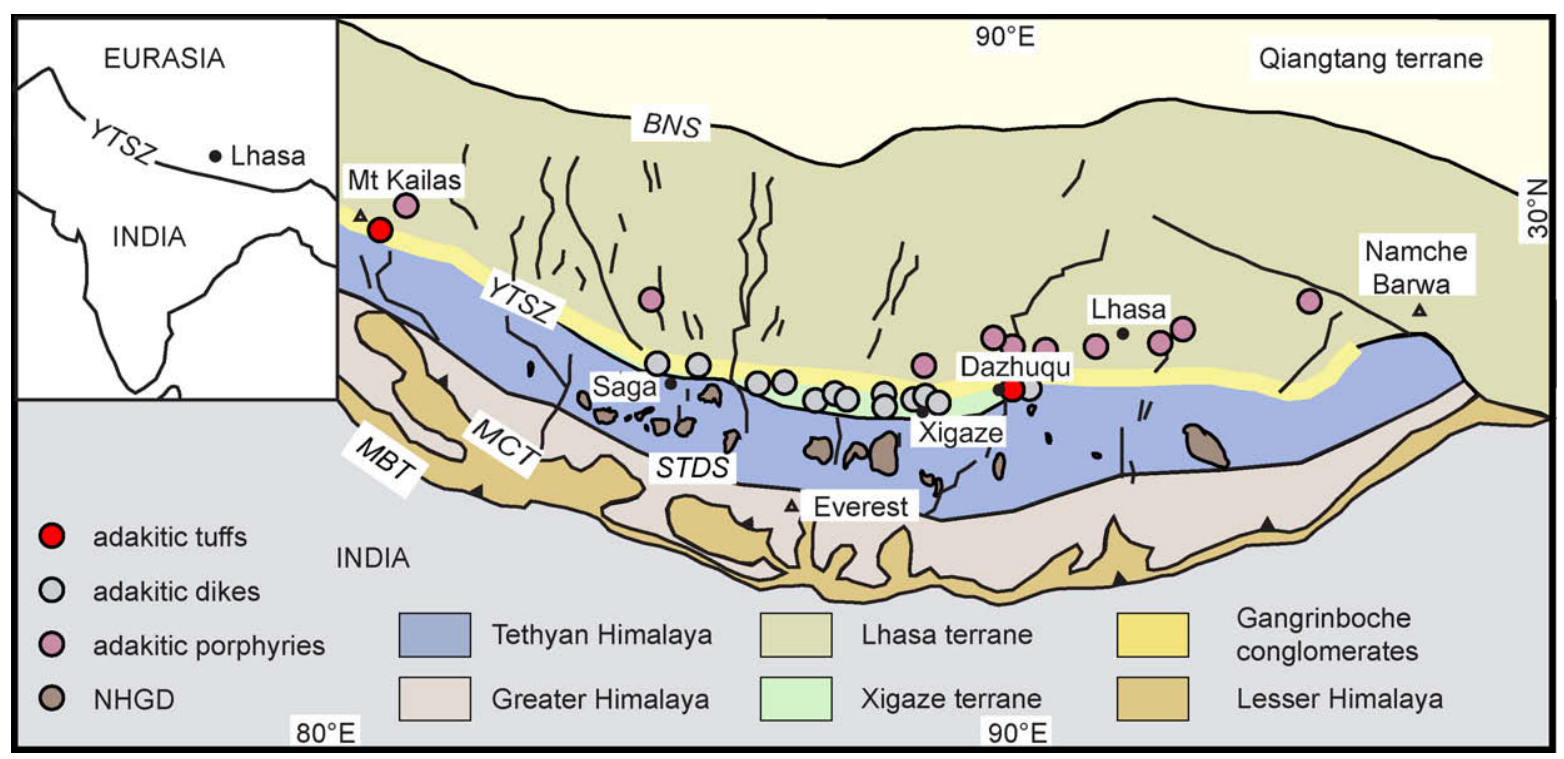

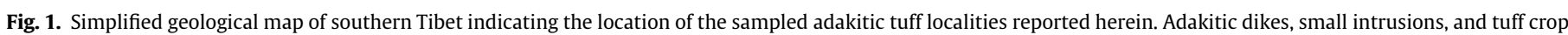

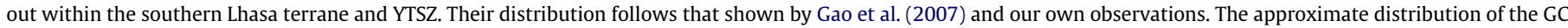

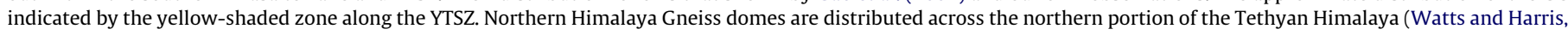

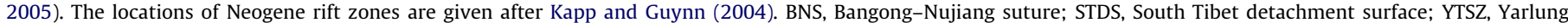

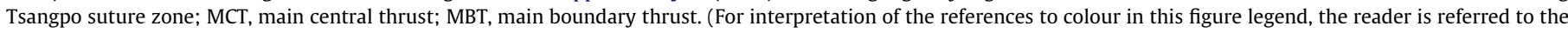
web version of this article.)

molasse (Searle et al., 1990). A remarkably consistent stratigraphic architecture is exhibited over $>1300 \mathrm{~km}$ strike length from east of Luobusa to beyond Mt. Kailas in western Tibet with broadly similar geological relationships existing at all localities (Aitchison et al., 2002; Chan, 2004; Davis et al., 2004). Although dissected by later erosion and tectonic disruption outcrop patterns indicate an E-W trending depositional system of considerable lateral extent, comparable to the modern Yarlung Tsangpo drainage system, developed to the north of the growing Himalayan mountain chain. Three large-scale members are observed in typical sections and sedimentary rocks at all localities exhibit characteristics compatible with increasing depositional system maturity from alluvial fan through braidplain environments. Many units are extremely proximal and clast petrography is influenced strongly by the nature of rocks in adjacent source terranes. Basal units of the GC are boulder conglomerates, which rest unconformably upon an eroded surface of southern Lhasa terrane rocks that served as the initial source of clastic detritus. Localised alluvial fan deposits indicate considerable relief on the southern Lhasa terrane. Up-section, the trend is towards axial (E-W) drainage and the first arrival of voluminous southerly-derived (suture zone and Tethyan Himalaya) clasts is abrupt. This marks the relative uplift of source areas along, and to the south of, the YTSZ with the flux of detritus from south of the suture increasing notably up-section.

An overall depositional model is applicable along the length of the YTSZ throughout the accumulation of these conglomerates. Facies architecture in this regionally distributed unit appears to reflect the original geometry of a major E-W oriented drainage system that developed axial to sub-parallel, active, flanking mountain ranges uplifted in response to back-thrusting during IndiaAsia convergence. The GC developed in association with erosion of mountains uplifted, first along the southern Lhasa terrane to the north of the YTSZ, then later syntectonically in response to north-directed back-thrusting south of the suture (Yin et al., 1999; Aitchison et al., 2002; Davis et al., 2004). N-S compression continued after GC deposition with these conglomerates and their Indus molasse correlatives, being affected by $\mathrm{N}$-vergent $\mathrm{E}-\mathrm{W}$ trending folds along their entire strike length (readers are referred to the cross sections in Burg and Chen, 1984; Burg et al., 1987; Searle et al., 1990).

As the GC is the oldest unit in which the presence of detritus sourced from either side of the YTSZ is unequivocal, its age is significant for the development of regional tectonic models. These conglomerates have long been regarded as providing a key minimum age constraint on Tethys closure and the timing of continental collision (Searle et al., 1987; Aitchison et al., 2007). Until now stratigraphic control has remained imprecise with the best estimates bracketing the GC within the Upper Oligocene to Lower Miocene (Aitchison et al., 2002). Recently published palynological studies (Li, 2004) are in accord with this age estimate. Radiometric dating of felsic tuffs reported herein provides the first precise direct age constraints on the timing of molasse sedimentation.

Uppermost levels of the conglomerates are truncated by southdipping thrust faults associated with the north-directed Great Counter thrust (GCT) system (Heim and Gansser, 1939; Gansser, 1964) or its lateral correlative further east, the Renbu-Zedong thrust (Yin et al., 1999). NW of Xigaze a related north-directed thrust places a hanging wall of Cretaceous forearc turbidites of the Xigaze terrane over the GC in its footwall. Notably, this fault is cut by an andesitic dike for which a mid-Miocene $(15.4 \pm 1.5 \mathrm{Ma}) \mathrm{K}$-feldspar cooling age $\left({ }^{40} \mathrm{Ar} /{ }^{39} \mathrm{Ar}\right)$ has been reported (Yin et al., 1994) indicating both that accumulation of the GC was completed by mid-Miocene time and that felsic magmatism continued beyond the cessation of GC deposition.

Both the conglomerates and GCT, which truncates them, are cut by $\mathrm{N}-\mathrm{S}$ trending normal faults. The development of these later structures thus clearly post-dates the onset of felsic magmatism. It reflects a significant change in tectonic regime and records the onset of E-W extension. The initiation of this extension is inferred to have been no earlier than Late Miocene in the Thakola graben (10-11 Ma in Garzione et al., 2003) and other localities such as the Nyainqentanglha Shan (Harrison et al., 1995). Recent work in the Kung Co graben, south of the YTSZ, provides direct age constraints, interpreted by Maheo et al. (2007) to limit the initiation of E-W extension until no earlier than $4 \mathrm{Ma}$. 


\section{Felsic tuffs}

Two widely separated localities at which feldspathic crystalrich tuffs are interbedded with conglomerates were discovered during detailed field investigations of the GC across Tibet. Thin parallel lamination and normal grading within the volcaniclastics, together with an absence of cross stratification, are characteristics of ash fallout deposits (McPhie et al., 1993). The localities, near Mt. Kailas and Dazhuqu, are separated by $\sim 800 \mathrm{~km}$ along regional strike yet they contain remarkably similar rocks. Preservation in the prevailing sedimentary environment of primary volcaniclastic units such as those described herein is fortuitous. Tuffaceous material deposited elsewhere was likely reworked in braided rivers and redeposited together with the normal clastic load of these systems. Local occurrences of conglomerate units with a highly feldspathic matrix found elsewhere (e.g. west of Xigaze) may represent additional volcaniclastic deposits.
Near Dazhuqu $\left(29^{\circ} 20.580^{\prime} \mathrm{N} / 089^{\circ} 38.278^{\prime} \mathrm{E}\right)$ a distinctive $11 \mathrm{~m}$ thick volcaniclastic horizon is encountered within the GC. South of the bridge crossing the Yarlung Tsangpo, boulder conglomerates unconformably overlie a surface eroded into porphyritic dacites of the southern Lhasa terrane. The tuff horizon occurs approximately $80 \mathrm{~m}$ up the section and is conformable within the detrital sequence. The crystal lithic tuffs contain are dominated by (1$3 \mathrm{~mm}$ ) plagioclase crystals accompanied by quartz and minor biotite. Angular volcanic lithic fragments $(1-2 \mathrm{~cm})$ are also present (Fig. 2A). The section continues with boulder to cobble-sized polymict conglomerates and a further thick $(45 \mathrm{~m})$ pyroclastic horizon crops out $\sim 100 \mathrm{~m}$ up-section.

Gently-dipping massive conglomerate beds form the bulk of Mt. Kailas and are part of a thick ( $4000 \mathrm{~m})$ section of GC that crops out in far western Tibet (Heim and Gansser, 1939; Gansser, 1964; Aitchison et al., 2002). As seen in many other sections, a depositional contact upon an eroded surface of southern Lhasa terrane rocks is observed with locally derived boulders of Kailas gran-
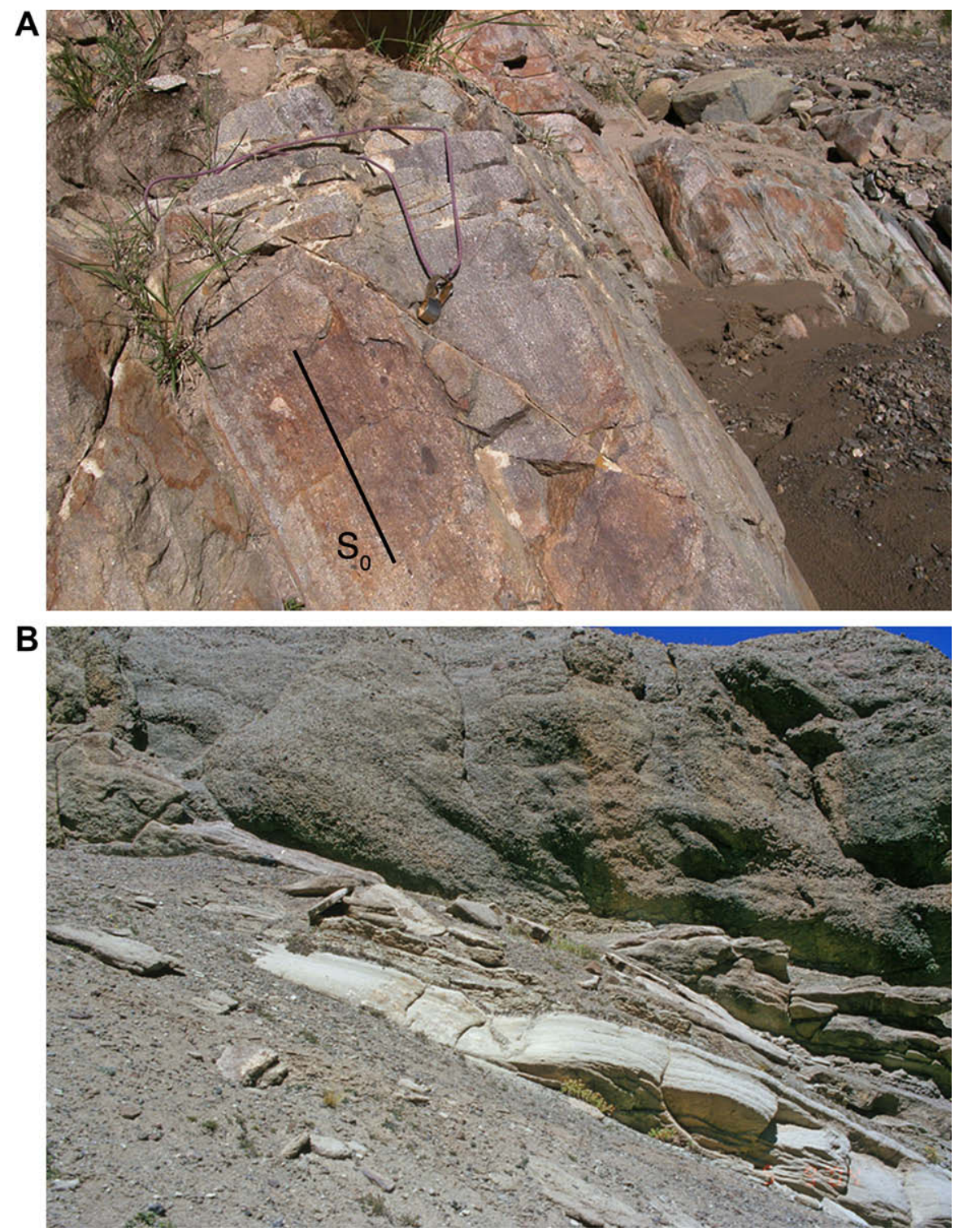

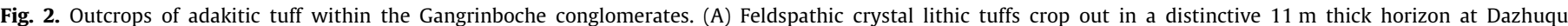

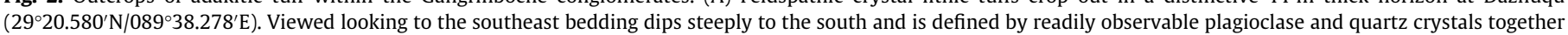

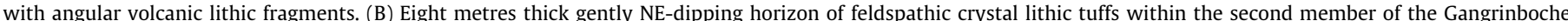

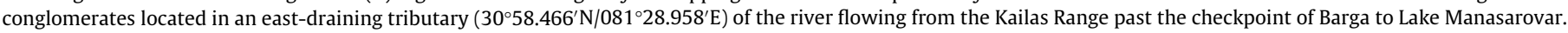
Viewed looking to the north. 
ite dominating the basal beds. The conglomerates can be broadly subdivided into three members (see stratigraphic sections in Aitchison et al., 2002). Thick laterally extensive tabular beds of sandstone and conglomerate predominate in the lower member with clasts compositions dominated by porphyritic Lhasa terrane volcanics. The middle member consists of massive conglomerates stacked in coarsening-upwards cycles. Southerly-derived quartzose sandstone clasts of Indian terrane origin are common and Lhasa terrane porphyritic volcanics become subordinate up-section. A transition to the upper member is observed with the gradual influx of beds of breccia derived from terranes that lie to the south of the Kailas Formation. Some clasts in the breccias are $>1 \mathrm{~m}^{3}$ and by the top of the upper member breccias dominate. Most clasts are of Tethyan origin with an abundance of boulders derived from the Indian terrane. Subordinate quantities of basalt, pelagic limestone, and red siliceous mudstone clasts are also present. The top of the GC is either faulted or removed by erosion. The conglomerates are locally overthrust by the north-directed Great Counter thrust (Gansser, 1964). An $8 \mathrm{~m}$ thick horizon of feldspathic crystal lithic tuffs (Fig. 2B) occurs within the second member of the conglomerates $\left(30^{\circ} 58.466^{\prime} \mathrm{N} / 081^{\circ} 28.958^{\prime} \mathrm{E}\right)$ in an east-draining tributary of the river flowing from the Kailas Range past the checkpoint at Barga downstream of which it drains into Lake Manasarovar.

The GC tuffs bear close mineralogical and geochemical similarity to elements of a regionally widespread suite of coeval intrusives that occur along the YTSZ (Miller et al., 1999; Chung et al., 2003; Gao et al., 2007). The geochemistry of these rocks is widely referred to as being 'adakitic', a term introduced by Defant and Drummond (1990) referring to andesites and dacites with distinctive geochemical signatures, such as extreme light REE concentrations, low Y

Table 1

Geochemical analyses for samples collected from tuffs and dikes within the Gangrinboche conglomerates

\begin{tabular}{|c|c|c|c|c|c|c|c|c|}
\hline $\begin{array}{l}\text { Sample } \\
\text { Location }\end{array}$ & $\begin{array}{l}\text { AD3-1 } \\
\text { Dazhuqu tuff }\end{array}$ & AD3-3 & AD3-4 & AD3-30 & AD3-31 & $\begin{array}{l}\text { AX5-27 } \\
\text { Bomo dike }\end{array}$ & $\begin{array}{l}\text { AN4-7 } \\
\text { Naguo dike }\end{array}$ & $\begin{array}{l}4090501 \\
\text { Kailas tuff }\end{array}$ \\
\hline${ }^{\circ} \mathrm{N}$ & $29^{\circ} 20.701^{\prime}$ & $29^{\circ} 20.701^{\prime}$ & $29^{\circ} 20.701^{\prime}$ & $29^{\circ} 20.701^{\prime}$ & $29^{\circ} 20.701^{\prime}$ & $29^{\circ} 20.345^{\prime}$ & $29^{\circ} 19.847^{\prime}$ & $30^{\circ} 58.466^{\prime}$ \\
\hline${ }^{\circ} \mathrm{E}$ & $089^{\circ} 38.268^{\prime}$ & $089^{\circ} 38.268^{\prime}$ & $089^{\circ} 38.268^{\prime}$ & $089^{\circ} 38.268^{\prime}$ & $089^{\circ} 38.268^{\prime}$ & $088^{\circ} 58.438^{\prime}$ & $088^{\circ} 42.930^{\prime}$ & $081^{\circ} 28.958^{\prime}$ \\
\hline $\mathrm{SiO}_{2}$ & 66.969 & 66.963 & 66.587 & 67.179 & 67.511 & 59.575 & 67.055 & 69.2 \\
\hline $\mathrm{TiO}_{2}$ & 0.417 & 0.385 & 0.313 & 0.329 & 0.333 & 0.758 & 0.747 & 0.23 \\
\hline $\mathrm{A}_{2} \mathrm{O}_{3}$ & 16.173 & 15.704 & 16.279 & 15.8 & 15.616 & 16.374 & 12.905 & 13.84 \\
\hline $\mathrm{Fe}_{2} \mathrm{O}_{3}$ & 2.699 & 2.699 & 2.018 & 2.305 & 2.372 & 4.499 & 5.612 & 1.59 \\
\hline $\mathrm{MnO}$ & 0.039 & 0.042 & 0.033 & 0.035 & 0.038 & 0.057 & 0.08 & 0.05 \\
\hline $\mathrm{MgO}$ & 0.953 & 0.955 & 0.64 & 0.618 & 0.71 & 2.288 & 1.566 & 1.45 \\
\hline $\mathrm{CaO}$ & 1.941 & 2.746 & 2.826 & 3.327 & 3.495 & 5.449 & 4.94 & 2.31 \\
\hline $\mathrm{Na}_{2} \mathrm{O}$ & 4.286 & 4.011 & 4.986 & 4.718 & 4.18 & 3.409 & 1.351 & 3.75 \\
\hline $\mathrm{K}_{2} \mathrm{O}$ & 3.451 & 3.003 & 2.611 & 2.412 & 2.867 & 1.974 & 2.09 & 2.39 \\
\hline $\mathrm{P}_{2} \mathrm{O}_{5}$ & 0.142 & 0.134 & 0.112 & 0.11 & 0.112 & 0.283 & 0.144 & 0.08 \\
\hline LOI & 2.393 & 2.335 & 3.008 & 2.322 & 2.357 & 3.81 & 2.091 & 3.88 \\
\hline Total & 99.463 & 98.977 & 99.413 & 99.155 & 99.591 & 98.476 & 98.581 & 98.77 \\
\hline $\mathrm{Li}$ & 36.36 & 28.22 & 31.14 & 21.21 & 24.13 & 6.504 & 17.3 & 7.272 \\
\hline $\mathrm{Be}$ & 2.546 & 2.259 & 2.186 & 2.335 & 2.559 & 2.121 & 2.872 & 2.001 \\
\hline Sc & 7.889 & 6.377 & 7.908 & 7.153 & 7.335 & 8.314 & 9.377 & 3.552 \\
\hline V & 50.12 & 49.5 & 42.05 & 41.31 & 40.45 & 102.3 & 85.33 & 26.01 \\
\hline $\mathrm{Cr}$ & 31.97 & 21.92 & 12.47 & 20.89 & 19.42 & 20.54 & 68.28 & 20.83 \\
\hline Co & 4.759 & 99.49 & 2.404 & 113.5 & 133.5 & 59.38 & 50.88 & 4.099 \\
\hline $\mathrm{Cu}$ & 38.64 & 33.52 & 47.91 & 28.42 & 19.71 & 64.61 & 42.67 & 5.973 \\
\hline $\mathrm{Zn}$ & 66.54 & 59.52 & 52.76 & 52.11 & 58.81 & 64.27 & 73.43 & 29.91 \\
\hline $\mathrm{Ga}$ & 19.01 & 18.77 & 18.35 & 18.39 & 18.49 & 17.62 & 19.13 & 18.02 \\
\hline $\mathrm{Rb}$ & 108 & 92.76 & 67.86 & 63.57 & 80.84 & 14.13 & 31.26 & 82.56 \\
\hline $\mathrm{Sr}$ & 657.3 & 710.5 & 785.7 & 744 & 943.3 & 660 & 1645 & 363.1 \\
\hline $\mathrm{Y}$ & 5.645 & 7.059 & 5.079 & 5.301 & 5.369 & 6.148 & 7.681 & 10.17 \\
\hline $\mathrm{Zr}$ & 136.8 & 129.3 & 118.5 & 104.7 & 111.9 & 91.71 & 150.4 & 126.8 \\
\hline $\mathrm{Nb}$ & 6.141 & 6.426 & 5.197 & 5.683 & 5.517 & 3.425 & 5.571 & 7.844 \\
\hline $\mathrm{Ba}$ & 758.3 & 753.3 & 757.1 & 631.6 & 723.2 & 61.5 & 1414 & 472.1 \\
\hline $\mathrm{La}$ & 22.46 & 25.87 & 18.19 & 22.98 & 23.5 & 16.7 & 31.32 & 54.94 \\
\hline $\mathrm{Ce}$ & 46.77 & 52.27 & 35.51 & 46.87 & 46.87 & 36.45 & 64.32 & 112.6 \\
\hline $\operatorname{Pr}$ & 5.286 & 5.777 & 4.274 & 5.275 & 5.244 & 4.59 & 7.639 & 11.82 \\
\hline $\mathrm{Nd}$ & 18.95 & 20.61 & 15.39 & 18.61 & 18.63 & 18.44 & 29.08 & 34.57 \\
\hline $\mathrm{Sm}$ & 3.096 & 3.505 & 2.546 & 3.066 & 3.034 & 3.3 & 4.937 & 5.44 \\
\hline $\mathrm{Eu}$ & 1.001 & 1.087 & 0.942 & 0.974 & 0.99 & 0.937 & 1.695 & 1.557 \\
\hline $\mathrm{Gd}$ & 2.599 & 2.865 & 2.032 & 2.521 & 2.57 & 2.58 & 4.044 & 6.078 \\
\hline $\mathrm{Tb}$ & 0.287 & 0.333 & 0.24 & 0.269 & 0.265 & 0.312 & 0.425 & 0.477 \\
\hline Dy & 1.251 & 1.473 & 1.077 & 1.128 & 1.146 & 1.353 & 1.741 & 1.994 \\
\hline Ho & 0.221 & 0.274 & 0.195 & 0.196 & 0.207 & 0.246 & 0.313 & 0.299 \\
\hline $\mathrm{Er}$ & 0.658 & 0.799 & 0.597 & 0.572 & 0.605 & 0.657 & 0.864 & 1.03 \\
\hline $\mathrm{Tm}$ & 0.095 & 0.11 & 0.079 & 0.081 & 0.083 & 0.086 & 0.109 & 0.133 \\
\hline $\mathrm{Yb}$ & 0.603 & 0.742 & 0.535 & 0.513 & 0.531 & 0.549 & 0.662 & 0.839 \\
\hline $\mathrm{Lu}$ & 0.085 & 0.11 & 0.083 & 0.08 & 0.081 & 0.081 & 0.1 & 0.123 \\
\hline $\mathrm{Hf}$ & 3.934 & 5.334 & 3.477 & 5.389 & 5.77 & 3.548 & 4.747 & 3.829 \\
\hline $\mathrm{Ta}$ & 0.638 & 2.099 & 0.775 & 2.099 & 2.331 & 0.815 & 0.924 & 1.066 \\
\hline W & 4.648 & 470.6 & 7.883 & 725.3 & 780.7 & 224.2 & 195.3 & 2.092 \\
\hline $\mathrm{Tl}$ & 0.734 & 0.726 & 0.622 & 0.496 & 0.572 & 0.08 & 0.279 & 0.615 \\
\hline $\mathrm{Pb}$ & 42.89 & 46.34 & 40.02 & 34.63 & 36.22 & 18.07 & 33.59 & 82.55 \\
\hline Th & 15.16 & 13.27 & 11.57 & 13.58 & 13.39 & 3.763 & 19.2 & 24.16 \\
\hline $\mathrm{U}$ & 3.635 & 3.781 & 2.37 & 3.199 & 3.176 & 0.732 & 2.631 & 4.794 \\
\hline
\end{tabular}

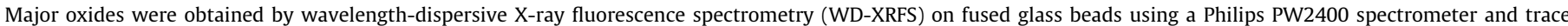

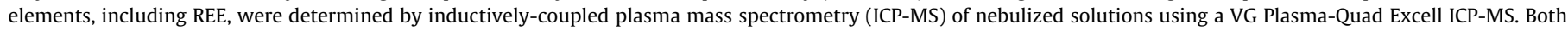
instruments are located at the University of Hong Kong. 
and heavy REE concentrations (e.g. $\mathrm{Y}<18 \mathrm{ppm}, \mathrm{Yb}<1.8 \mathrm{ppm}$ ), very high $\mathrm{Sr} / \mathrm{Y}$ ratios $(>50)$ and $\mathrm{La} / \mathrm{Yb}$ ratios $(>9)$. We note that although the term adakite is widely applied it is perhaps best used parsimoniously. Some of the commonly cited characteristics are not necessarily unique to adakites and simply indicate the presence of residual garnet in the source or fractional crystallisation with garnet segregation. However, the purpose of this manuscript is not a discussion of the use of the term adakite. Rather, it is to note the presence of eruptive equivalents of such rocks amongst sedimentary units for which the tectonic setting and depositional environment is well constrained and thereby places constraints on the tectonic setting in which magmatism occurred. The Dazhuqu tuffs, in particular, have high $\mathrm{Sr} / Y$ ratios similar to the characteristic 'adakitic' fingerprint of the southern Tibet suite whereas the Kailas sample appears to have more calc-alkaline affinity and is perhaps best regarded as dacitic (Table 1 and Fig. 3). We also note that the age of the Kailas sample (discussed below) bears close similarity to that of geochemically similar calc-alkaline volcanics previously reported from (?pyroclastic) debris flows along the shores of Lake Manasarovar (Miller et al., 1999).

Three samples of felsic tuff were collected from the GC (two from Dazhuqu and one from Kailas). Biotite and plagioclase separates from Dazhuqu tuffs and a plagioclase separate from the Kailas tuff were dated by ${ }^{40} \mathrm{Ar} /{ }^{39} \mathrm{Ar}$ step-heating and single-grain fusion methods using furnace and laser heating techniques at the Department of Geosciences, National Taiwan University using techniques documented in detail by Lo et al. (2002). The $J$-values are calculated using argon compositions of the LP- 6 biotite standard, with a ${ }^{40} \mathrm{Ar} /{ }^{39} \mathrm{Ar}$ age of $128.4 \pm 0.2 \mathrm{Ma}$, calibrated according to the age of the Fish Canyon biotite by assuming that it has the same age as the Fish Canyon sanidine (28.02 $\pm 0.28 \mathrm{Ma})$ (Renne et al., 1998). Ages were calculated from $\mathrm{Ar}$ isotopic ratios measured after corrections made for mass discrimination, interfering nuclear reactions, procedural blanks, and atmospheric Ar contamination. Detailed results of the ${ }^{40} \mathrm{Ar} /{ }^{39} \mathrm{Ar}$ experiments of this study are given in the Background Dataset, and the data are plotted as age spectra (Fig. 4) and on isotope correlation diagrams (Fig. 5). Biotite and plagioclase separates from the Dazhuqu tuff samples were dated by both step-heating and total fusion methods. Biotite from sample 31A yielded a plateau age of $24.1 \pm 0.7 \mathrm{Ma}$ whereas plagioclase yielded $19.5 \pm 0.1$ and $19.7 \pm 0.5 \mathrm{Ma}$ from samples $31 \mathrm{~A}$ and $31 \mathrm{~B}$, respectively. On the isotope correlation diagrams, the intercept ages and ${ }^{40} \mathrm{Ar} /{ }^{36} \mathrm{Ar}$ initial values are $22.3 \pm 0.7$ and $308.3 \pm 6.5 \mathrm{Ma}(31 \mathrm{~A}$ biotite), $19.5 \pm 0.2$ and $295.3 \pm 1.6 \mathrm{Ma}$ (31A plagioclase), and

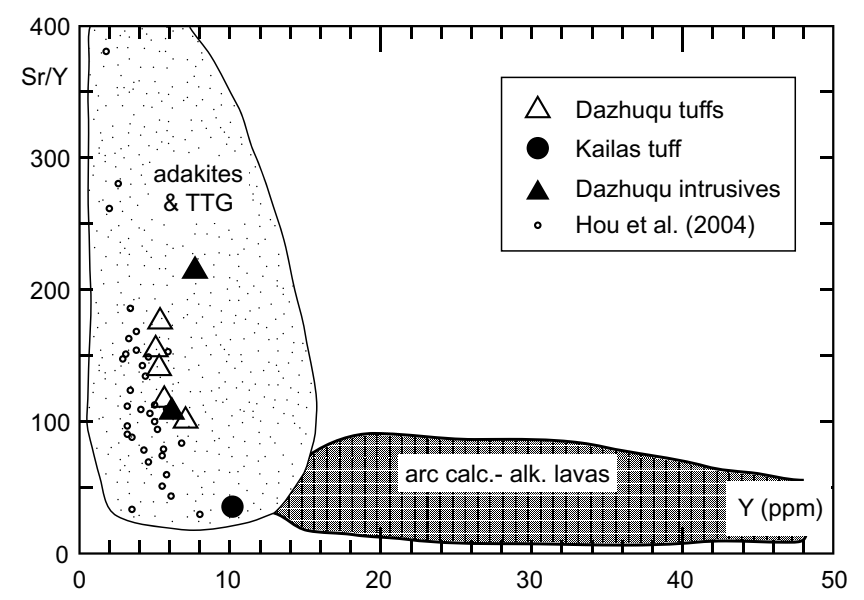

Fig. 3. Plot of $\mathrm{Sr} / \mathrm{Y}$ vs. $\mathrm{Y}$ for felsic tuffs from the Gangrinboche tuffs. Fields for average adakites and tonalite-trondhjemite-granodiorite (TTG) and island arc calcalkaline lavas (after Chung et al., 2003) are shown. Data for other adakitic rocks from Tibet (Hou et al., 2004) are also shown.
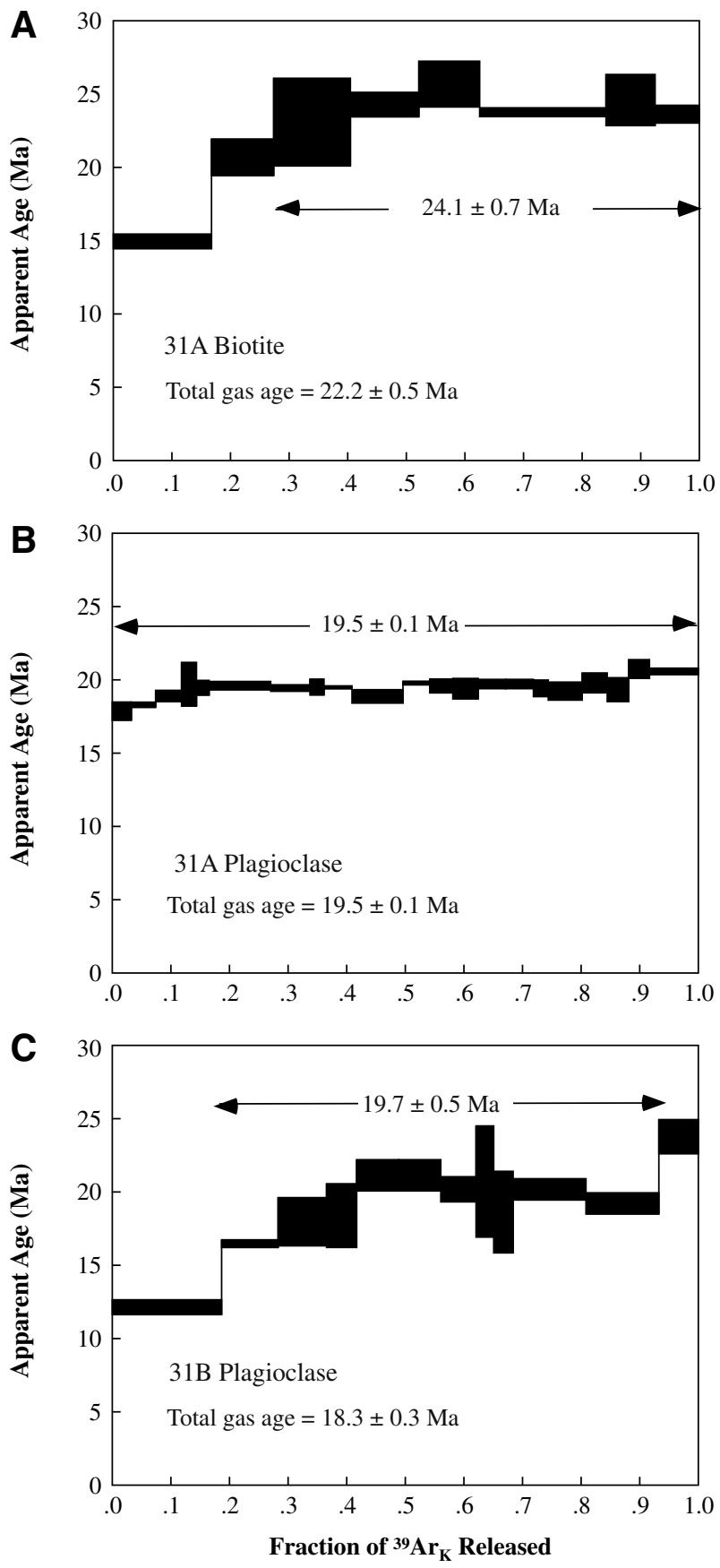

Fig. 4. Apparent age spectra of the step-heating analyses mineral separates from felsic tuff samples collected from within the Gangrinboche tuffs: (A) biotite from Dazhuqu tuff sample 31A, (B) plagioclase from Dazhuqu tuff sample 31A, (C) plagioclase from Dazhuqu tuff sample 31B. Plateau ages are calculated within arrows, which indicate gas fractions used for plateau age calculations. The vertical height of each step, shown as black horizontal bars, represents the $2 \sigma$ external error. All errors shown are $1 \sigma$, which includes uncertainties derived from the age of the irradiation standard.

$20.1 \pm 0.5$ and $295.0 \pm 1.5 \mathrm{Ma}$ (31B plagioclase), The intercept ages, in consideration with the data distribution and individual errors, are in good agreement with the plateau dates obtained by the step-heating experiments. We note the difference between the slightly older biotite ages from sample $31 \mathrm{~A}$ and those for separates of plagioclase. Given that the sample collected is an airfall tuff it seems improbable that discrepancies between the biotite and plagioclase ages can be explained as different cooling ages. The ages for plagioclase from sample $31 \mathrm{~A}$ calculated by both methods 

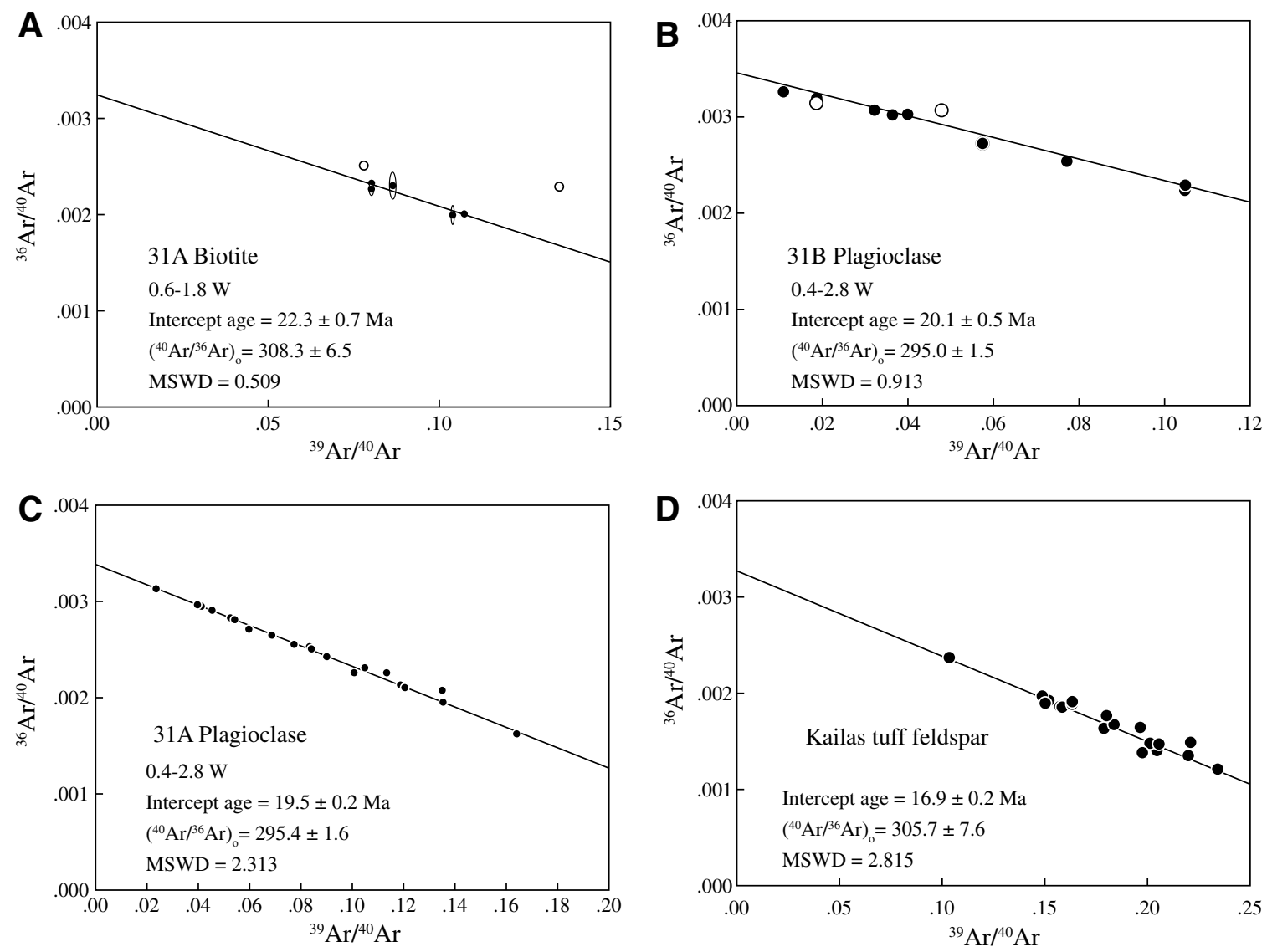

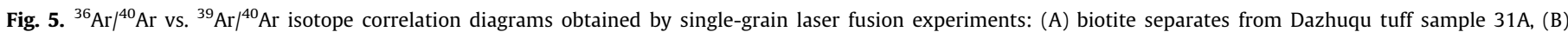

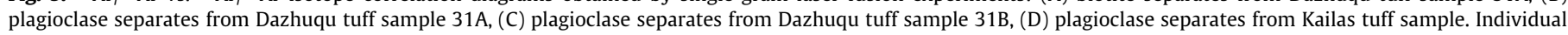
data points are presented by solid circles, with $1 \sigma$ error ellipses.

are in very close accord with one another with the smallest standard deviation (19.5 $\pm<0.2 \mathrm{Ma}$ ). Plagioclase separated from the Kailas tuff sample was also dated using the total fusion method. On the isotope correlation diagrams, it gives an intercept age of $16.9 \pm 0.2 \mathrm{Ma}$ and an initial value of $295.0 \pm 1.5 \mathrm{Ma}$, which is very close to (within error of) atmospheric argon composition.

\section{Discussion}

The depositional setting of the GC is well-constrained. Thus discovery and dating of felsic tuffs interbedded with these fluvial conglomerates places limitations on models for the Early Miocene tectonic evolution of southern Tibet. Such models need to embrace all temporally indistinguishable features during this important time in the evolution of the Tibetan Plateau. Even by the youngest published estimates (Aitchison et al., 2007), India-Asia collision was well underway and the plateau was already uplifted to levels similar to its present-day altitude (Spicer et al., 2003; Rowley and Currie, 2006; DeCelles et al., 2007). Harrison et al. (1992) report a notable acceleration in rock uplift rates upon the Tibetan Plateau around $20 \mathrm{Ma}$ signifying an important change in regional tectonics.

Sedimentary facies present and their architecture indicate deposition of the GC in a braided river system analogous to the present-day Yarlung Tsangpo on the northern edge of the growing Himalayan mountain chain. From our own regional investigations, we can further elucidate some crucial aspects of Early Miocene regional structural evolution. The narrow elongate basin across southern Tibet in which the GC sedimentary package accumulated extends along the entire length of the suture zone between India and Asia and developed in association with a N-S compressional regime (Aitchison et al., 2002). Initial uplift occurred north of the suture within the Lhasa terrane. Subsequently, areas to the south were also uplifted and shed detritus into the basin.

Intrusion of numerous granodioritic/dacitic porphyries into the southern Lhasa terrane was penecontemporaneous with molasse deposition along a range front at the southern edge of the Lhasa terrane. Pyroclastic eruptions from local volcanic centres likely contributed felsic tuffs to the fluvial succession and their serendipitous escape from later fluvial erosion allows us to constrain the overall tectonic context and surficial environment in which magmatism occurred. Although many workers associate this magmatism with E-W extension across the plateau (see below) the presence of tuffs in the GC clearly suggests it initiated under a $\mathrm{N}-\mathrm{S}$ compressional regime. The conglomerates and intercalated felsic tuffs are truncated by, and lie within the footwall of, the north-directed GCT. Later felsic dikes intrude across the north-directed GCT back-thrust system indicating on-going magmatic activity. Active $\mathrm{N}-\mathrm{S}$ trending normal faults associated with $\mathrm{E}-\mathrm{W}$ extension, a notable feature of the Tibet Plateau (Molnar and Tapponnier, 1978), cut and therefore post-date, both the GC and the GCT. The associated transition from N-S compressional to E-W extensional tectonic regimes is indirectly inferred to have occurred no earlier than the beginning of the Late Miocene (Harrison et al., 1995; Garzione et al., 2003).

Dating of the GC tuffs indicates that emplacement of North Himalayan granite/gneiss domes (NHGD) was also broadly coeval with accumulation of the GC. The domes are regionally extensive and crop out along a belt sub-parallel to and locally $<25 \mathrm{~km}$ south of the felsic tuff-bearing GC along the YTSZ. Several recent descrip- 
tions also suggest that dome emplacement was associated with a tectonic regime initially involving $\mathrm{N}-\mathrm{S}$ contraction followed by top to the north extension (Lee et al., 2000, 2004; Aoya et al., 2005; Quigley et al., 2006, 2007). Potentially, this could have generated the relative uplift necessary to provide a southern source of detritus shed into the GC and may have been linked to north-directed back-thrusting (GCT) nearer the suture.

The occurrence of 20-17 Ma tuffs within the GC provides firstorder constraints on the tectonic regime that prevailed when felsic magmatism began. Linkages have been widely postulated between convective removal ('delamination') of the lower part of the lithosphere under Tibet and its replacement by hot asthenosphere causing elevation of the geotherm and melt generation (England and Houseman, 1989; Turner et al., 1993, 1996; Williams et al., 2001, 2004; Chung et al., 2003; Hou et al., 2004; Qu et al., 2004). Based on the N-S orientation of felsic dikes $(n=7)$ in the Daggyai Tso graben and at Pubbai Zong, Williams et al. (2001) inferred temporal and spatial links between E-W extension and sub-continental lithospheric mantle-derived magmatism. We note that as most early geological expeditions to southern Tibet were constrained by the transport infrastructure that links permanent human settlements associated with fertile land along river drainages they tended to follow $\mathrm{N}-\mathrm{S}$ oriented valley systems, which cut across the plateau. Initial reports of Early Miocene felsic intrusives were of dikes from such valleys (Williams et al., 2001) and possibly record the influence of local stress fields. We have examined dikes across a wider region and although still small our own database of observations ( $n=21$; Table 2 ) suggests little or no preferred orientation (Fig. 6). Regional investigations, in particular $\mathrm{Cu}-\mathrm{Mo}-\mathrm{Au}$ exploration near Lhasa, also reveal that granodioritic dikes and porphyries, although volumetrically minor, are widespread across southern Tibet with their occurrence defining an arcuate E-W trending zone along and immediately north of the YTSZ (Gao et al., 2007) that is not necessarily confined to rift zones.

The prevailing, and increasingly popular, model applied to interpretation of the formation of both the NHGD and Greater Himalayan sequence invokes ductile flow through a mid-crustal channel structure (Beaumont et al., 2001; Law et al., 2006) from beneath southern Tibet (Lhasa terrane) under the YTSZ to the Greater Himalayan domain in southern Tibet with a major ductile shear zone, the Main Central Thrust, marking the base of the channel and the STDS at the top. The model potentially explains production of the NHGD and postulated links whereby a positive feed back mechanism exists between erosion and uplift involving channel flow through the mid to lower crust of Tibet. Material entrained in mid-crustal regions of the Indian plate is channelled southwards from under the southern Lhasa terrane to both the site of the NHGD and the Greater Himalaya. A significant zone of partial melt is postulated to exist below and north of the YTSZ, an interpretation that is consistent with geophysical observations from INDEPTH studies of present-day southern Tibet (Nelson et al., 1996). However, if an extensive zone of melt were present in a mid-crustal channel during the Early Miocene, the propagation of a fracture system such as would be required to facilitate rapid trans-lithospheric migration of an adakitic melt from its lower crustal or lithospheric mantle source region to the surface of southern Tibet (Spera, 1987; Williams et al., 2001) appears problematic.

King et al. (2007) report the occurrence of felsic dikes a few $\mathrm{km}$ south of the YTSZ. These 12-9 Ma dikes, however, are significantly $(\geqslant 5$ m.y.) younger than the felsic tuffs described herein and likely post-date the transition to an E-W extensional regime. Geochemical data suggest they shared the same source as the older (Early Miocene) dikes north of the suture. From this they infer that the dikes were sourced from crustal melts of the mid-lower crust of the Asian Plate entrained in a southward ductile flow. However, the dikes do not necessarily provide support for, nor do they re-
Table 2

Orientations (strike, dip, location) of Miocene dikes measured in southern Tibet $(n=21)$

\begin{tabular}{|c|c|c|c|}
\hline Strike & Dip & Lat $\left({ }^{\circ} \mathrm{N}\right)$ & Long $\left({ }^{\circ} \mathrm{E}\right)$ \\
\hline 250 & 62 & $29^{\circ} 13.130$ & $088^{\circ} 11.770$ \\
\hline 345 & V & $29^{\circ} 12.929$ & $088^{\circ} 20.402$ \\
\hline 270 & 60 & $29^{\circ} 12.929$ & $088^{\circ} 20.402$ \\
\hline 290 & 80 & $29^{\circ} 12.698$ & $088^{\circ} 21.165$ \\
\hline 180 & 25 & $29^{\circ} 10.942$ & $088^{\circ} 24.318$ \\
\hline 275 & 80 & $29^{\circ} 11.509$ & $088^{\circ} 33.861$ \\
\hline 175 & 80 & $29^{\circ} 10.153$ & $088^{\circ} 42.973$ \\
\hline 170 & 85 & $29^{\circ} 10.153$ & $088^{\circ} 42.973$ \\
\hline 084 & 30 & $29^{\circ} 18.870$ & $088^{\circ} 46.434$ \\
\hline 142 & $\mathrm{~V}$ & $29^{\circ} 17.961$ & $088^{\circ} 45.979$ \\
\hline 076 & 60 & $29^{\circ} 17.473$ & $088^{\circ} 45.394^{\prime}$ \\
\hline 073 & 60 & $29^{\circ} 17.290$ & $088^{\circ} 45.562$ \\
\hline 076 & 85 & $29^{\circ} 18.157$ & $088^{\circ} 45.150$ \\
\hline 096 & 30 & $29^{\circ} 19.138$ & $088^{\circ} 47.486$ \\
\hline 031 & 20 & $29^{\circ} 19.385$ & $088^{\circ} 47.735$ \\
\hline 124 & 80 & $29^{\circ} 19.297$ & $088^{\circ} 47.693$ \\
\hline 122 & 15 & $29^{\circ} 19.050$ & $088^{\circ} 47.155$ \\
\hline 030 & 35 & $29^{\circ} 13.520$ & $088^{\circ} 53.775$ \\
\hline 060 & 20 & $29^{\circ} 15.915$ & $088^{\circ} 57.970$ \\
\hline 120 & 55 & $29^{\circ} 18.495$ & $088^{\circ} 52.155$ \\
\hline \multirow[t]{2}{*}{095} & 34 & $29^{\circ} 19.145$ & $088^{\circ} 50.965$ \\
\hline & & Location & \\
\hline 022 & V & Pabbai Zong & \\
\hline 159 & V & Pabbai Zong & \\
\hline 008 & V & Pabbai Zong & \\
\hline 157 & V & Pabbai Zong & \\
\hline 000 & V & Pabbai Zong & \\
\hline 000 & V & Daggyai Tso & \\
\hline 025 & V & Daggyai Tso & \\
\hline
\end{tabular}

Strikes of dikes at Pabbai Zong and Daggyai Tso reported by Williams et al. (2001) are also given.

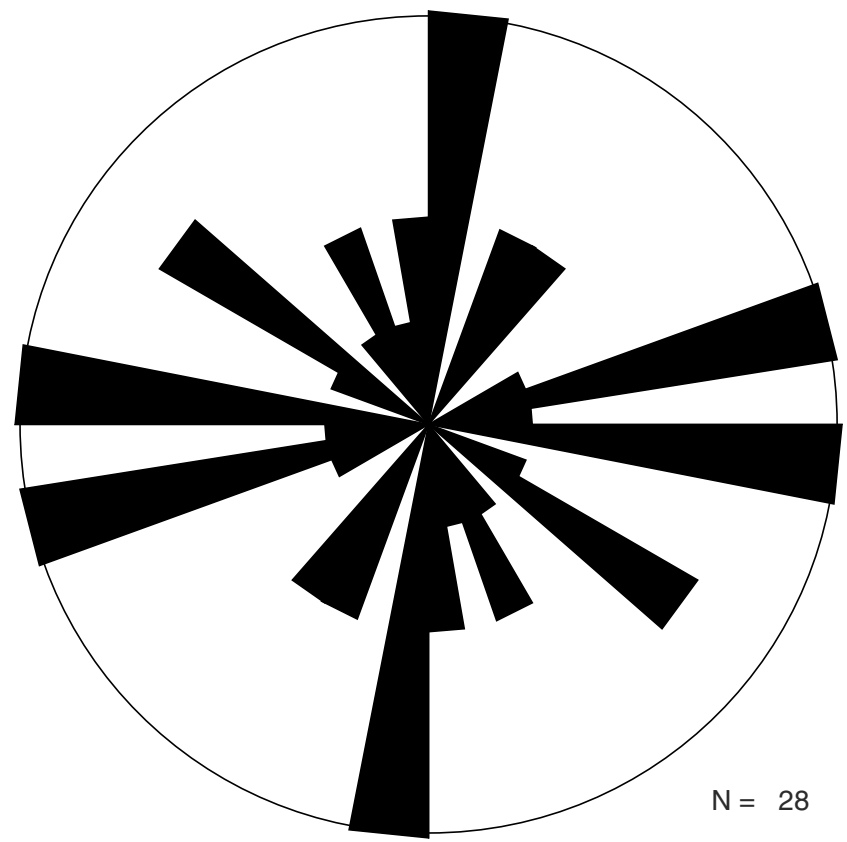

Fig. 6. Rose diagram of structural observations of the orientations of Miocene dikes in the vicinity of Xigaze (11 dikes) together with data for intrusions at Daggyai Tso $(n=2)$ and Pabbai Zong $(n=5)$ reported by Williams et al. (2001).

quire, ductile channel flow. By the time these younger dikes were intruded northern Himalaya Tethyan rocks had been back-thrust in the hanging wall of the GCT system northwards over a footwall of suture zone and southern Lhasa terrane strata. Thus, Asian Plate rocks potentially already tectonically underlay the site at which the dikes were intruded. 
An explanation that accommodates magmatic products within the tectonic setting that prevailed in southern Tibet during the Early Miocene is required. Petrographic constraints and geochemistry indicate that Cenozoic felsic intrusives in Tibet were derived from melting of lower crustal eclogites or garnet amphibolites (Chung et al., 2003; Gao et al., 2007). We note that this is the subject of some debate with other authors presenting a case for an upper mantle source metasomatized by slab-derived melts (Wang et al., 2005; Gao et al., 2007). Together with the GC, which formed under a $\mathrm{N}-\mathrm{S}$ compressional regime, they are distributed in an arcuate E-W trending zone along and north of the YTSZ. This likely reflects the orientation of their source area in the lower crust or upper mantle. In contemporary settings where similar (adakitic) melts are being generated they are commonly interpreted to form in association with flat subduction and possible slab break-off (Gutscher et al., 2000a, 2000b; Haschke et al., 2002). It has already been suggested that increased uplift at $21 \mathrm{Ma}$ and buoyant rebound of Indian crust may have been associated with a slab break-off event initiating at around $25 \mathrm{Ma}$ (Chemenda et al., 2000; Mahéo et al., 2002). Williams et al. (2004) also favour slab break-off as an explanation for adakites in southern Tibet with the caveat that the same model does not necessarily provide an explanation for similar rocks in areas further north of the YTSZ.

We suggest that a slab break-off model not only satisfies criteria required by the presence of the majority of rock units present in southern Tibet and associated uplift, it is more consistent with a late ( $\sim 35 \mathrm{Ma})$ rather than early ( $\leqslant 55 \mathrm{Ma})$ collision. Based on assumptions discussed by Leech et al. (2005) break-off would likely occur when continental crust attained the depths at which UHP metamorphism occurs and where buoyancy forces overcome slab pull. Using a starting point of $35 \mathrm{Ma}$ for initiation of collision and taking a minimum estimate of $4.5 \mathrm{~cm} / \mathrm{yr}$ convergence between India and Asia in the next 10 m.y. (Guillot et al., 2003) until the postulated slab break-off event, it can be inferred that $450 \mathrm{~km}$ of continental slab should be been subducted under Tibet by 25 Ma. (N.B. at convergence rates calculated between India and Asia a $55 \mathrm{Ma}$ collision would require subduction/under-thrusting of $1350 \mathrm{~km}$ of Indian lithosphere beneath Tibet prior to a $25 \mathrm{Ma}$ break-off event). Slab break-off would most likely have initiated near the continent/ocean lithosphere transition on the down-going slab and would therefore have been more or less parallel to the YTSZ. In modern settings from which adakitic volcanism has been observed (Gutscher et al., 2000a,b; Haschke et al., 2002; Haschke and Ben-Avraham, 2005) subduction occurs at a low angle prior to slab break-off. Following slab break-off in the Early Miocene, on-going underthrusting of buoyant lithosphere (Indian crust) under southern Tibet may have led to the development of a zone of adakitic magmatism above a tongue of asthenospheric material entrained between slices of Asian and Indian lithospheres. This conjecture is consistent with the pattern of distribution of the GC and the products of adakitic magmatism. We suggest that further exploration of potential links between slab break-off and generation of the NHGD may also prove fruitful.

\section{Acknowledgments}

We thank members of the Tibetan Ministry of Geology and Resources and the Tibetan Geological Society as well as fellow members of the HKUTRG whose efforts have helped to make this research possible. Many of our Tibetan friends have assisted with arranging logistics and permission. This work was supported by grants (to J.C.A.) from the Research Grants Council of the Hong Kong Special Administrative Region, China (Project HKU 001/04P) and the HKU CRCG. Ms. Fu Xiao and Dr. Xiao Xiaoping are thanked for their assistance with geochemical analyses and Gavin Chan is thanked for assistance with preparing mineral separates for analysis. We thank Jeff Lee, Nigel Harris, Jean-Pierre Burg, Nick Arnaud, Herve LeLoup and Paul Kapp for helpful reviews of iterations of this manuscript.

\section{Appendix. Background Dataset}

Results of Laser ${ }^{40} \mathrm{Ar} /{ }^{39} \mathrm{Ar}$ step-heating experiments for mineral separates from felsic tuff samples collected from within the Gangrinboche tuffs.

Results of Laser ${ }^{40} \mathrm{Ar} /{ }^{39} \mathrm{Ar}$ step-heating experiments for Dazhuqu tuffs

\begin{tabular}{|c|c|c|c|c|c|c|c|c|}
\hline E & Cum. ${ }^{39} \mathrm{Ar}_{\mathrm{K}}$ & Atmos. (\%) & ${ }^{36} \mathrm{Ar} /{ }^{39} \mathrm{Ar}$ & ${ }^{37} \mathrm{Ar} /{ }^{39} \mathrm{Ar}$ & ${ }^{38} \mathrm{Ar} /{ }^{39} \mathrm{Ar}$ & ${ }^{40} \mathrm{Ar} /{ }^{39} \mathrm{Ar}$ & ${ }^{40} \mathrm{Ar} /{ }^{36} \mathrm{Ar}$ & Age (Ma) \\
\hline \multicolumn{9}{|c|}{ 31A Biotite } \\
\hline 0.2 & .168 & 67.7 & $.1697 \mathrm{E}-01$ & $.1488 E-02$ & $.8980 \mathrm{E}-01$ & $.7435 E+01$ & $.4382 E+03$ & $14.9 \pm .5$ \\
\hline 0.4 & .274 & 74.2 & $.3221 \mathrm{E}-01$ & $.2350 \mathrm{E}-02$ & $.2259 E+00$ & $.1286 \mathrm{E}+02$ & $.3993 E+03$ & $20.7 \pm 1.3$ \\
\hline 0.6 & .405 & 68.0 & $.2665 \mathrm{E}-01$ & $.8257 \mathrm{E}-02$ & $.1482 E+00$ & $.1161 E+02$ & $.4355 E+03$ & $23.1 \pm 3.0$ \\
\hline 0.7 & .521 & 68.8 & $.2902 E-01$ & $.2134 \mathrm{E}-02$ & $.1486 E+00$ & $.1250 \mathrm{E}+02$ & $.4308 E+03$ & $24.3 \pm .8$ \\
\hline 0.8 & .625 & 67.0 & $.2828 \mathrm{E}-01$ & $.2404 \mathrm{E}-02$ & $.1512 \mathrm{E}+00$ & $.1251 E+02$ & $.4423 E+03$ & $25.7 \pm 1.6$ \\
\hline 0.9 & .841 & 59.2 & $.1878 \mathrm{E}-01$ & $.2116 \mathrm{E}+00$ & $.1328 \mathrm{E}+00$ & $.9374 \mathrm{E}+01$ & $.4992 E+03$ & $23.8 \pm .3$ \\
\hline 1.2 & 1.000 & 59.3 & $.1872 E-01$ & $.3303 E-02$ & $.1199 E+00$ & $.9350 \mathrm{E}+01$ & $.4996 \mathrm{E}+03$ & $23.6 \pm .6$ \\
\hline
\end{tabular}

$J$-value $=0.00347774 \pm 0.00001195$.

Integrated age $=22.2 \pm 0.5 \mathrm{Ma}$.

Plateau age $=24.1 \pm 0.7 \mathrm{Ma}(0.4-1.2 \mathrm{~W})$.

31A Plagioclase

\section{$0.4 \quad 033$}

$0.6 \quad .074$

$0.8 \quad .118$

$1.0 \quad .144$

$1.2 \quad .165$

1.3

.165
.270

61.4

66.8

74.8

92.6

83.6

71.7
$.1538 E-01$
$.1993 E-01$
$.3037 E-01$
$.1329 E+00$
$.5388 E-01$
$.2696 E-01$
$.1483 E-01$
$.1902 E-01$
$.1988 E-01$
$.4723 E-01$
$.2857 E-01$
$.2318 E-01$
$.7435 \mathrm{E}+01$

$.8849 \mathrm{E}+01$

$.1203 \mathrm{E}+02$

$.4246 \mathrm{E}+02$

$.1907 \mathrm{E}+02$

$.1114 \mathrm{E}+02$
$.4834 \mathrm{E}+03$

$.4440 \mathrm{E}+03$

$.3961 \mathrm{E}+03$

$.3195 \mathrm{E}+03$

$.3539 \mathrm{E}+03$

$.4131 \mathrm{E}+03$
$17.9 \pm .6$

$18.3 \pm .2$

$18.9 \pm .4$

$19.7 \pm 1.5$

$19.5 \pm .5$

$19.6 \pm .3$ 
Appendix (continued)

\begin{tabular}{|c|c|c|c|c|c|c|c|c|}
\hline $\mathrm{E}$ & Cum. ${ }^{39} \mathrm{Ar}_{\mathrm{K}}$ & Atmos. (\%) & ${ }^{36} \mathrm{Ar} /{ }^{39} \mathrm{Ar}$ & ${ }^{37} \mathrm{Ar} /{ }^{39} \mathrm{Ar}$ & ${ }^{38} \mathrm{Ar} /{ }^{39} \mathrm{Ar}$ & ${ }^{40} \mathrm{Ar} /{ }^{39} \mathrm{Ar}$ & ${ }^{40} \mathrm{Ar} /{ }^{36} \mathrm{Ar}$ & Age (Ma) \\
\hline 1.4 & .337 & 63.0 & $.1796 \mathrm{E}-01$ & $.7400 \mathrm{E}-02$ & $.2035 E-01$ & $.8450 \mathrm{E}+01$ & $.4705 E+03$ & $19.4 \pm .2$ \\
\hline 1.5 & .361 & 83.1 & $.5191 \mathrm{E}-01$ & $.1875 E-01$ & $.2786 \mathrm{E}-01$ & $.1849 E+02$ & $.3562 E+03$ & $19.5 \pm .5$ \\
\hline 1.6 & .409 & 57.7 & $.1444 \mathrm{E}-01$ & $.3846 E-03$ & $.1860 \mathrm{E}-01$ & $.7418 E+01$ & $.5138 E+03$ & $19.5 \pm .1$ \\
\hline 1.8 & .542 & 48.0 & $.9905 E-02$ & $.4018 \mathrm{E}-03$ & $.1495 E-01$ & $.6126 \mathrm{E}+01$ & $.6184 \mathrm{E}+03$ & $19.8 \pm .1$ \\
\hline 1.9 & .581 & 62.2 & $.1748 \mathrm{E}-01$ & $.4664 \mathrm{E}-03$ & $.1682 \mathrm{E}-01$ & $.8331 E+01$ & $.4767 E+03$ & $19.6 \pm .5$ \\
\hline 2.0 & .624 & 87.2 & $.7170 \mathrm{E}-01$ & $.1506 \mathrm{E}-01$ & $.3244 \mathrm{E}-01$ & $.2432 E+02$ & $.3392 E+03$ & $19.4 \pm .7$ \\
\hline 2.3 & .744 & 87.7 & $.7479 E-01$ & $.5853 E-01$ & $.3563 E-01$ & $.2524 \mathrm{E}+02$ & $.3374 \mathrm{E}+03$ & $19.4 \pm .6$ \\
\hline 2.4 & .802 & 74.1 & $.2983 E-01$ & $.3172 E-03$ & $.2254 \mathrm{E}-01$ & $.1192 E+02$ & $.3998 E+03$ & $19.2 \pm .6$ \\
\hline 2.5 & .845 & 75.5 & $.3305 E-01$ & $.1253 E-01$ & $.2474 \mathrm{E}-01$ & $.1297 E+02$ & $.3923 E+03$ & $19.8 \pm .7$ \\
\hline 2.6 & .881 & 86.0 & $.6415 E-01$ & $.2070 \mathrm{E}-01$ & $.2961 E-01$ & $.2208 E+02$ & $.3442 E+03$ & $19.3 \pm .8$ \\
\hline 2.7 & .917 & 80.2 & $.4544 \mathrm{E}-01$ & $.5162 E-03$ & $.2218 \mathrm{E}-01$ & $.1678 E+02$ & $.3693 E+03$ & $20.7 \pm .6$ \\
\hline \multicolumn{9}{|c|}{ 31B Plagioclase } \\
\hline 0.4 & .187 & 90.7 & $.6413 \mathrm{E}-01$ & $.3247 E-03$ & $.2778 \mathrm{E}-01$ & $.2092 E+02$ & $.3262 E+03$ & $12.1 \pm .5$ \\
\hline 0.6 & .283 & 89.5 & $.7583 E-01$ & $.6284 \mathrm{E}-03$ & $.2614 \mathrm{E}-01$ & $.2507 E+02$ & $.3307 E+03$ & $16.5 \pm .3$ \\
\hline 0.8 & .366 & 90.7 & $.9542 \mathrm{E}-01$ & $.7331 E-03$ & $.3293 E-01$ & $.3110 \mathrm{E}+02$ & $.3260 E+03$ & $18.0 \pm 1.6$ \\
\hline 1.0 & .417 & 89.3 & $.8307 \mathrm{E}-01$ & $.6393 E-01$ & $.3339 E-01$ & $.2752 E+02$ & $.3312 E+03$ & $18.4 \pm 2.2$ \\
\hline 1.2 & .489 & 80.5 & $.4745 E-01$ & $.4341 \mathrm{E}-01$ & $.2777 \mathrm{E}-01$ & $.1744 \mathrm{E}+02$ & $.3675 E+03$ & $21.1 \pm 1.1$ \\
\hline 1.4 & .561 & 80.5 & $.4745 E-01$ & $.4341 \mathrm{E}-01$ & $.2733 E-01$ & $.1744 \mathrm{E}+02$ & $.3675 E+03$ & $21.1 \pm 1.1$ \\
\hline 1.6 & .621 & 75.0 & $.3292 \mathrm{E}-01$ & $.1007 \mathrm{E}-02$ & $.1243 E-01$ & $.1299 E+02$ & $.3946 E+03$ & $20.2 \pm .9$ \\
\hline 1.8 & .651 & 96.4 & $.2995 E+00$ & $.2011 \mathrm{E}-02$ & $.7229 E-01$ & $.9185 E+02$ & $.3067 E+03$ & $20.7 \pm 3.8$ \\
\hline 2.0 & .684 & 94.4 & $.1711 \mathrm{E}+00$ & $.1828 \mathrm{E}-02$ & $.4766 \mathrm{E}-01$ & $.5359 E+02$ & $.3131 E+03$ & $18.6 \pm 2.8$ \\
\hline 2.2 & .808 & 66.1 & $.2137 \mathrm{E}-01$ & $.4875 E-03$ & $.1907 \mathrm{E}-01$ & $.9577 E+01$ & $.4482 E+03$ & $20.2 \pm .7$ \\
\hline 2.3 & .933 & 67.7 & $.2186 \mathrm{E}-01$ & $.4872 E-03$ & $.1977 \mathrm{E}-01$ & $.9566 \mathrm{E}+01$ & $.4377 E+03$ & $19.2 \pm .7$ \\
\hline
\end{tabular}

Note: E: laser energy in watts.

$J$-value: weighted mean of three fusions of irradiation standard LP-6 Biotite having a calibrated.

${ }^{40} \mathrm{Ar} /{ }^{39} \mathrm{Ar}$ age of $128.4 \pm 0.2 \mathrm{Ma}$, based on Fish Canyon Sanidine (28.02 $\pm 0.28 \mathrm{Ma}$ ) (Baksi et al., 1996; Renne et al., 1998).

The age is obtained by using the following equations:

Date $=\frac{1}{\lambda} \ln \left(1+J \frac{{ }^{40} \mathrm{Ar}^{*}}{{ }^{39} \mathrm{Ar}_{\mathrm{k}}}\right)$, and

$\frac{{ }^{40} \mathrm{Ar}^{*}}{{ }^{39} \mathrm{Ar}_{\mathrm{k}}}=\frac{\left[{ }^{40} \mathrm{Ar} /{ }^{39} \mathrm{Ar}\right]_{\mathrm{m}}-295.5\left[{ }^{36} \mathrm{Ar} /{ }^{39} \mathrm{Ar}\right]_{\mathrm{m}}+295.5\left[{ }^{36} \mathrm{Ar} /{ }^{37} \mathrm{Ar}\right]_{\mathrm{Ca}}\left[{ }^{37} \mathrm{Ar} /{ }^{39} \mathrm{Ar}\right]_{\mathrm{m}}}{1-\left[{ }^{39} \mathrm{Ar} /{ }^{37} \mathrm{Ar}\right]_{\mathrm{Ca}}\left[{ }^{37} \mathrm{Ar} /{ }^{39} \mathrm{Ar}\right]_{\mathrm{m}}}-\left[\frac{{ }^{40} \mathrm{Ar}}{{ }^{39} \mathrm{Ar}}\right]_{\mathrm{k}}$

where [ $]_{\mathrm{Ca}}$ and []$_{\mathrm{k}}=$ isotope ratios of argon extracted from irradiated calcium and potassium salts (values cited in the text) and [ $]_{\mathrm{m}}=$ isotope ratio of argon extracted from irradiated unknown.

Age $(\mathrm{Ma})=$ the age calculated using the following decay constants: $\lambda \varepsilon=0.581 \times 10^{-10} \mathrm{yr}^{-1} ; \lambda_{\beta}=4.962 \times 10^{-10} \mathrm{yr}^{-1}$; $\lambda=5.543 \times 10^{-10} \mathrm{yr}^{-1} ;{ }^{40} \mathrm{~K} / \mathrm{K}=0.01167$ atom\% (Steiger and Jäger, 1977).

The quoted error is one standard deviation and includes the error in the standard error, but does not include the error in the interference corrections.

Results of ${ }^{40} \mathrm{Ar} /{ }^{39} \mathrm{Ar}$ laser single-grain fusion experiments

\begin{tabular}{lllllll}
\hline No. & Atmos. (\%) & ${ }^{36} \mathrm{Ar} /{ }^{39} \mathrm{Ar}$ & ${ }^{37} \mathrm{Ar} /{ }^{39} \mathrm{Ar}$ & ${ }^{38} \mathrm{Ar} /{ }^{39} \mathrm{Ar}$ & ${ }^{40} \mathrm{Ar} /{ }^{39} \mathrm{Ar}$ & ${ }^{40} \mathrm{Ar} /{ }^{36} \mathrm{Ar}$ \\
\hline $\begin{array}{l}\text { Kailas tuff feldspar } \\
1\end{array}$ & 56.87 & $.12679 \mathrm{E}-01$ & $.64594 \mathrm{E}-01$ & $.19044 \mathrm{E}-01$ & $.66084 \mathrm{E}+01$ & $.52122 \mathrm{E}+03$ \\
2 & 58.24 & $.13259 \mathrm{E}-01$ & $.29577 \mathrm{E}-01$ & $.18875 \mathrm{E}-01$ & $.67518 \mathrm{E}+01$ & $.50922 \mathrm{E}+03$ \\
3 & 44.03 & $.67513 \mathrm{E}-02$ & $.36423 \mathrm{E}-01$ & $.14745 \mathrm{E}-01$ & $.45539 \mathrm{E}+01$ & $.67451 \mathrm{E}+03$ \\
4 & 48.33 & $.91594 \mathrm{E}-02$ & $.49314 \mathrm{E}-01$ & $.17260 \mathrm{E}-01$ & $.56210 \mathrm{E}+01$ & $.61369 \mathrm{E}+03$ \\
5 & 70.07 & $.22940 \mathrm{E}-01$ & $.79427 \mathrm{E}-01$ & $.21720 \mathrm{E}-01$ & $.96942 \mathrm{E}+01$ & $.42260 \mathrm{E}+03$ \\
6 & 41.51 & $.68723 \mathrm{E}-02$ & $.24228 \mathrm{E}-01$ & $.12046 \mathrm{E}-01$ & $.49162 \mathrm{E}+01$ & $.71535 \mathrm{E}+03$
\end{tabular}

(continued on next page) 


\begin{tabular}{|c|c|c|c|c|c|c|c|}
\hline No. & Atmos. (\%) & ${ }^{36} \mathrm{Ar} /{ }^{39} \mathrm{Ar}$ & ${ }^{37} \mathrm{Ar} /{ }^{39} \mathrm{Ar}$ & ${ }^{38} \mathrm{Ar} /{ }^{39} \mathrm{Ar}$ & ${ }^{40} \mathrm{Ar} /{ }^{39} \mathrm{Ar}$ & ${ }^{40} \mathrm{Ar} /{ }^{36} \mathrm{Ar}$ & Date (Ma) \\
\hline 7 & 43.76 & $.73700 \mathrm{E}-02$ & $.40707 \mathrm{E}-01$ & $.15642 \mathrm{E}-01$ & $.49986 \mathrm{E}+01$ & $.67823 E+03$ & $17.5 \pm .1$ \\
\hline 8 & 35.80 & $.51816 \mathrm{E}-02$ & $.37100 \mathrm{E}-01$ & $.15868 \mathrm{E}-01$ & $.42984 E+01$ & $.82956 E+03$ & $17.1 \pm .2$ \\
\hline 9 & 55.04 & $.11846 E-01$ & $.46032 \mathrm{E}-01$ & $.19794 \mathrm{E}-01$ & $.63823 E+01$ & $.53878 E+03$ & $17.8 \pm .2$ \\
\hline 10 & 54.84 & $.11726 \mathrm{E}-01$ & $.47685 E-01$ & $.18638 E-01$ & $.63400 \mathrm{E}+01$ & $.54070 \mathrm{E}+03$ & $17.8 \pm .1$ \\
\hline 11 & 43.52 & $.71744 \mathrm{E}-02$ & $.40588 \mathrm{E}-01$ & $.16705 E-01$ & $.48927 \mathrm{E}+01$ & $.68198 E+03$ & $17.2 \pm .1$ \\
\hline 12 & 42.78 & $.70765 E-02$ & $.35941 \mathrm{E}-01$ & $.16583 E-01$ & $.49108 E+01$ & $.69396 E+03$ & $17.4 \pm .3$ \\
\hline 13 & 39.96 & $.61583 E-02$ & $.34882 E-01$ & $.16784 \mathrm{E}-01$ & $.45765 E+01$ & $.74314 \mathrm{E}+03$ & $17.1 \pm .3$ \\
\hline 14 & 55.73 & $.11566 \mathrm{E}-01$ & $.76802 \mathrm{E}-01$ & $.18122 \mathrm{E}-01$ & $.61515 E+01$ & $.53184 E+03$ & $16.9 \pm .2$ \\
\hline 15 & 56.53 & $.11730 \mathrm{E}-01$ & $.76786 \mathrm{E}-01$ & $.18118 \mathrm{E}-01$ & $.61502 E+01$ & $.52431 E+03$ & $16.6 \pm .2$ \\
\hline 16 & 40.85 & $.70891 E-02$ & $.35430 \mathrm{E}+00$ & $.14408 \mathrm{E}-01$ & $.50908 E+01$ & $.71812 E+03$ & $18.7 \pm .4$ \\
\hline 17 & 48.61 & $.86797 E-02$ & $.12314 \mathrm{E}+01$ & $.14879 E-01$ & $.51140 \mathrm{E}+01$ & $.58919 E+03$ & $16.3 \pm .2$ \\
\hline 18 & 49.50 & $.91299 \mathrm{E}-02$ & $.46264 \mathrm{E}-01$ & $.17224 \mathrm{E}-01$ & $.54723 E+01$ & $.59939 E+03$ & $17.2 \pm .3$ \\
\hline 19 & 56.04 & $.12632 E-01$ & $.16651 \mathrm{E}-01$ & $.13436 \mathrm{E}-01$ & $.66871 E+01$ & $.52935 E+03$ & $18.3 \pm .7$ \\
\hline 20 & 52.23 & $.98316 \mathrm{E}-02$ & $.57787 \mathrm{E}-01$ & $.17486 \mathrm{E}-01$ & $.55827 E+01$ & $.56783 E+03$ & $16.6 \pm .7$ \\
\hline
\end{tabular}

$J$-value $=0.00347774 \pm 0.00001195$.

Total gas age $=17.4 \pm 0.1 \mathrm{Ma}$.

Mean age $=17.4 \mathrm{STDEV}=0.7 \mathrm{Ma}$.

Note: J-value: Weighted mean of three fusions of irradiation standard Fish Canyon Sanidine having a calibrated ${ }^{40} \mathrm{Ar} /{ }^{39} \mathrm{Ar}$ age of $28.02 \pm 0.28$ Ma (Renne et al., 1998).

The date is obtained by using the following equations:

Date $=\frac{1}{\lambda} \ln \left(1+J \frac{{ }^{40} \mathrm{Ar}^{*}}{{ }^{39} \mathrm{Ar}_{\mathrm{k}}}\right)$, and

$\frac{{ }^{40} \mathrm{Ar}^{*}}{{ }^{39} \mathrm{Ar}_{\mathrm{k}}}=\frac{\left[{ }^{40} \mathrm{Ar} /{ }^{39} \mathrm{Ar}\right]_{\mathrm{m}}-295.5\left[{ }^{36} \mathrm{Ar} /{ }^{39} \mathrm{Ar}\right]_{\mathrm{m}}+295.5\left[{ }^{36} \mathrm{Ar} /{ }^{37} \mathrm{Ar}\right]_{\mathrm{Ca}}\left[{ }^{37} \mathrm{Ar} /{ }^{39} \mathrm{Ar}\right]_{\mathrm{m}}}{1-\left[{ }^{39} \mathrm{Ar} /{ }^{37} \mathrm{Ar}\right]_{\mathrm{Ca}}\left[{ }^{37} \mathrm{Ar} /{ }^{39} \mathrm{Ar}\right]_{\mathrm{m}}}-\left[\frac{{ }^{40} \mathrm{Ar}}{{ }^{39} \mathrm{Ar}}\right]_{\mathrm{k}}$

where []$_{\mathrm{Ca}}$ and []$_{\mathrm{k}}=$ isotope ratios of argon extracted from irradiated calcium and potassium salts (values cited in the text) and [ $]_{\mathrm{m}}=$ isotope ratio of argon extracted from irradiated unknown.

Date $(\mathrm{Ma})=$ the date calculated using the following decay constants: $\lambda \varepsilon=0.581 \times 10^{-10} \mathrm{yr}^{-1} ; \lambda_{\beta}=4.962 \times 10^{-10} \mathrm{yr}^{-1} ; \lambda=5.543 \times 10^{-10}$ $\mathrm{yr}^{-1} ;{ }^{40} \mathrm{~K} / \mathrm{K}=0.01167$ atom \% (Steiger and Jäger, 1977).

The quoted error is one standard deviation and includes the error in the standard error, but doesn't include the error in the interference corrections.

\section{References}

Aitchison, J.C., Ali, J.R., Davis, A.M., 2007. When and where did India and Asia collide? Journal of Geophysical Research, Solid Earth 112, B05423. doi:10.1029/2006JB004706.

Aitchison, J.C., Davis, A.M., Badengzhu, Luo, H., 2002. New constraints on the IndiaAsia collision: the Lower Miocene Gangrinboche conglomerates, Yarlung Tsangpo suture zone, SE Tibet. Journal of Asian Earth Sciences 21, 253-265.

Aoya, M., Wallis, S.R., Terada, K., Lee, J., Kawakami, T., Wang, Y., Heizler, M., 2005 North-south extension in the Tibetan crust triggered by granite emplacement. Geology 33, 853-856.

Baksi, A.K., Archibald, D.A., Farrar, E., 1996. Intercalibration of ${ }^{40} \mathrm{Ar} /{ }^{39} \mathrm{Ar}$ dating standards. Chemical Geology 129, 307-324.

Beaumont, C., Jamieson, R.A., Nguyen, M.H., Lee, B., 2001. Himalayan tectonics explained by extrusion of a low-viscosity crustal channel coupled to focused surface denudation. Nature 414, 738-742.

Beaumont, C., Jamieson, R.A., Nguyen, M.H., Medvedev, S., 2004. Crustal channel flows: 1. Numerical models with applications to the tectonics of the Himalayan-Tibetan orogen. Journal of Geophysical Research 109, B06406. doi:10.1029/2003JB002809.

Burg, J.P., Chen, G.M., 1984. Tectonics and structural zonation of southern Tibet, China. Nature 311, 219-223.

Burg, J.P., Leyreloup, A., Girardeau, J., Chen, G.M., 1987. Structure and metamorphism of a tectonically thickened continental crust; the Yalu Tsangpo suture zone (Tibet). Philosophical Transactions of the Royal Society of London, Series A: Mathematical and Physical Sciences 321, 67-86.

Chan, O.K.A., 2004. Miocene Collision-Related Conglomerates, South Tibet. M. Phil. Thesis, University of Hong Kong, Hong Kong, 164 pp.

Chemenda, A.I., Burg, J.-P., Mattauer, M., 2000. Evolutionary model of the Himalaya-Tibet system: geopoem: based on new modelling, geological and geophysical data. Earth and Planetary Science Letters 174, 397-409.

Chung, S.-L., Chu, M.-F., Zhang, Y., Xie, Y., Lo, C.-H., Lee, T.-Y., Lan, C.-Y., Li, X., Zhang, Q., Wang, Y., 2005. Tibetan tectonic evolution inferred from spatial and temporal variations in post-collisional magmatism. Earth-Science Reviews 68, 173-196.

Chung, S.-L., Liu, D., Ji, J., Chu, M.-F., Lee, H.-Y., Wen, D.-J., Lo, C.-H., Lee, T.-Y., Qian, Q., Zhang, Q., 2003. Adakites from continental collision zones: melting of thickened lower crust beneath southern Tibet. Geology 31, 10211024.

Chung, S.-L., Lo, C.H., Lee, T.Y., Zhang, Y.Q., Xie, Y.W., Li, X.H., Wang, K.L., Wang, P.L., 1998. Diachronous uplift of the Tibetan plateau starting $40 \mathrm{Myr}$ ago. Nature 394, 769-773.

Collins, W.J., 1994. Upper- and middle-crustal response to delamination: An example from the Lachlan fold belt, eastern Australia. Geology 22, 143146.

Davis, A.M., Aitchison, J.C. Badengzhu, Hui, L, 2004. Conglomerates of the Yarlung Tsangpo suture zone, southern Tibet. In: Malpas, J.G., Fletcher, C.J.N., Ali, J.R., Aitchison, J.C. (Eds.), Aspects of the Tectonic Evolution of China. Geological Society of London, Special Publication No. 226. The Geological Society, London, UK, pp. 235-246.

DeCelles, P.G., Kapp, P., Ding, L., Gehrels, G.E., 2007. Late Cretaceous to middle Tertiary basin evolution in the central Tibetan Plateau: Changing environments in response to tectonic partitioning, aridification, and regional elevation gain. Geological Society of America Bulletin 119, 654-680.

Defant, M.J., Drummond, M.S., 1990. Derivation of some modern arc magmas by melting of young subducted lithosphere. Nature 347, 662-665.

England, P.C. Houseman, G.A. 1989. Extension during continental convergence, with application to the Tibetan Plateau. Journal of Geophysical Research, Part B: Solid Earth 94, 17561-17579.

Gansser, A., 1964. The Geology of the Himalayas. Wiley-Interscience, New York $289 \mathrm{pp}$.

Gao, Y., Hou, Z., Kamber, B.S., Wei, R., Meng, X., Zhao, R., 2007. Adakite-like porphyries from the southern Tibetan continental collision zones: evidence for slab melt metasomatism. Contributions to Mineralogy and Petrology 153, 105120.

Garzione, C.N., DeCelles, P.G., Hodkinson, D.G., Ojha, T.P., Upreti, B.N., 2003. Eastwest extension and Miocene environmental change in the southern Tibetan Plateau: Thakkhola graben, central Nepal. Geological Society of America Bulletin 115, 3-20.

Guillot, S., Garzanti, E., Baratoux, D., Marquer, D., Mahéo, G., de Sigoyer, J., 2003. Reconstructing the total shortening history of the NW Himalaya. Geochemistry, Geophysics, and Geosystem 4 (7). doi:10.1029/2002GC000484. Gutscher, M.-A., Maury, R., Eissen, J.-P., Bourdon, E., 2000a. Can slab melting be caused by flat subduction? Geology 28, 535-538. 
Gutscher, M.-A., Spakman, W., Bijwaard, H., Engdahl, E.R., 2000b. Geodynamics of flat subduction: Seismicity and tomographic constraints from the Andean margin. Tectonics 19, 814-833.

Harrison, T.M., Copeland, P., Kidd, W.S.F., Lovera, O.M., 1995. Activation of the Nyainquentanghla shear zone: Implications for uplift of the southern Tibetan Plateau. Tectonics 14, 658-676.

Harrison, T.M., Copeland, P., Kidd, W.S.F., Yin, A., 1992. Raising Tibet. Science 255 1663-1670.

Haschke, M., Ben-Avraham, Z., 2005. Adakites from collision-modified lithosphere. Geophysical Research Letters 32, L15302. doi:10.1029/2005GL023468.

Haschke, M.R., Scheuber, E., Gunther, A., Reutter, K.J., 2002. Evolutionary cycles during the Andean orogeny: repeated slab breakoff and flat subduction? Terra Nova $14,49-55$

Heim, A., Gansser, A., 1939. Central Himalaya: geological observations of the Swiss Expedition. Mémoires de la Société Helvétique des Sciences Naturelles 73, 1245.

Hou, Z.-Q., Gao, Y.-F., Qu, X.-M., Rui, Z.-Y., Mo, X.-X., 2004. Origin of adakitic intrusives generated during mid-Miocene east-west extension in southern Tibet. Earth and Planetary Science Letters 220, 139-155.

Houseman, G., England, P., 1996. A lithospheric-thickening model for the Indo-Asian collision. In: Yin, A., Harrison, T.M. (Eds.), The Tectonic Evolution of Asia. Cambridge University Press, New York, pp. 1-17.

Jamieson, R.A., Beaumont, C., Medvedev, S., Nguyen, M.H., 2004. Crustal channel flows: 2. Numerical models with implications for metamorphism in the Himalayan-Tibetan orogen. Journal of Geophysical Research 109, B06407. doi:10.1029/2003JB002811.

Kapp, P., Guynn, J.H., 2004. Indian punch rifts Tibet. Geology 32, 993-996.

King, J., Harris, N., Argles, T., Parrish, R.R., Charlier, B., Sherlock, S., Zhang, H.F., 2007. First field evidence of southward ductile flow of Asian crust beneath southern Tibet. Geology 35, 727-730.

Law, R.D., Searle, M.P., Godin, L. (Eds.), 2006. Channel Flow, Extrusion, and Exhumation in Continental Collision Zones. Geological Society, London, Special Publications, 268. Geological Society, London, p. 620.

Lee, J., Hacker, B., Wang, Y., 2004. Evolution of North Himalayan gneiss domes: structural and metamorphic studies in Mabja Dome, southern Tibet. Journal of Structural Geology 26, 2297-2316.

Lee, J., Hacker, B.R., Dinklage, W.S., Gans, P.B., Calvert, A., Wang, Y., Wan, J., Chen W.J., 2000. Evolution of the Kangmar Dome, southern Tibet: Structural, petrologic, and thermochronologic constraints. Tectonics 19, 872-895.

Leech, M.L., Singh, S., Jain, A.K., Klemperer, S.L., Manickavasagam, R.M., 2005. The onset of India-Asia continental collision: early, steep subduction required by the timing of UHP metamorphism in the western Himalaya. Earth and Planetary Science Letters 234, 83-97.

Li, J.G., 2004. Discovery and preliminary study on palynofossils from the Cenozoic Qiuwu Formation of Xizang (Tibet). Acta Micropalaeontologica Sinica 21, 216 221.

Lo, C.-H., Chung, S.-L., Lee, T.-Y., Wu, G., 2002. Age of the Emeishan flood magmatism and relations to Permian-Triassic boundary events. Earth and Planetary Science Letters 198, 449-458.

Mahéo, G., Guillot, S., Blichert-Toft, J., Rolland, Y., Pêcher, A., 2002. A slab breakoff model for the Neogene thermal evolution of South Karakorum and South Tibet. Earth and Planetary Science Letters 195, 45-58.

Maheo, G., Leloup, P.H., Valli, F., Lacassin, R., Arnaud, N., Paquette, J.L., Fernandez, A. Haibing, L., Farley, K.A., Tapponnier, P., 2007. Post $4 \mathrm{Ma}$ initiation of normal faulting in southern Tibet. Constraints from the Kung Co half graben. Earth and Planetary Science Letters 256, 233-243.

McPhie, J., Doyle, M.G., Allen, R., 1993. Volcanic Textures: A Guide to the Interpretation of Textures in Volcanic Rocks. Centre for Ore Deposit and Exploration Studies, University of Tasmania, Hobart, Tas. 190 pp.

Miller, C., Schuster, R., Klötzli, U., Frank, W., Purtscheller, F., 1999. Post-collisional potassic and ultrapotassic magmatism in SW Tibet: Geochemical and Sr-Nd$\mathrm{Pb}-\mathrm{O}$ isotopic constraints for mantle source characteristics and petrogenesis Journal of Petrology 40, 1399-1424.

Molnar, P., Tapponnier, P., 1978. Active tectonics of Tibet. Journal of Geophysica Research 83, 5361-5375.

Nelson, K.D., Zhao, W., Brown, L.D., Kuo, J., Che, J., Liu, X., Klemperer, S.L., Makovsky, Y., Meissner, R., Mechie, J., Kind, R., Wenzel, F., Ni, J., Nabelek, J., Chen, L., Tan, H.
Wei, W., Jones, A.G., Booker, J., Unsworth, M., Kidd, W.S.F., Hauck, M., Alsdorf, D., Ross, A., Cogan, M., Wu, C., Sandvol, E.A., Edwards, M., 1996. Partially molten middle crust beneath southern Tibet; synthesis of Project INDEPTH results. Science 274, 1684-1688.

Nomade, S., Renne, P.R., Mo, X., Zhao, Z., Zhou, S., 2004. Miocene volcanism in the Lhasa block, Tibet: spatial trends and geodynamic implications. Earth and Planetary Science Letters 221, 227-243.

Qu, X., Hou, Z., Li, Y., 2004. Melt components derived from a subducted slab in late orogenic ore-bearing porphyries in the Gangdese copper belt, southern Tibetan plateau. Lithos 74, 131-148.

Quigley, M., Liangjun, Y., Xiaohan, L., Wilson, C.J.L., Sandiford, M., Phillips, D., 2006. ${ }^{40} \mathrm{Ar} /{ }^{39} \mathrm{Ar}$ thermochronology of the Kampa Dome, southern Tibet: Implications for tectonic evolution of the North Himalayan gneiss domes. Tectonophysics 421, 269-297.

Quigley, M.C., Liangjun, Y., Gregory, C., Corvino, A., Sandiford, M., Wilson, C.J.L., Xiaohan, L., 2007. U-Pb SHRIMP zircon geochronology and T-t-d history of the Kampa Dome, southern Tibet. Tectonophysics. doi:10.1016/j.tecto.2007.11.004.

Renne, P.R., Swisher, C.C., Deino, A.L., Karner, D.B., Owens, T.L., DePaolo, D.J., 1998. Intercalibration of standards, absolute ages and uncertainties in ${ }^{40} \mathrm{Ar} /{ }^{39} \mathrm{Ar}$ dating. Chemical Geology 145, 117-152.

Rowley, D.B., Currie, B.S., 2006. Palaeo-altimetry of the late Eocene to Miocene Lunpola basin, central Tibet. Nature 439, 677-681.

Searle, M.P., Pickering, K.T., Cooper, D.J.W., 1990. Restoration and evolution of the intermontane Indus molasse basin, Ladakh Himalaya, India. Tectonophysics 174, 301-314.

Searle, M.P., Windley, B.F., Coward, M.P., Cooper, D.J.W., Rex, A.J., Rex, D., Li, T., Xiao, X., Jan, M.Q., Thakur, V.C., Kumar, S., 1987. The closing of Tethys and the tectonics of the Himalaya. Geological Society of America Bulletin 98, 678-701.

Spera, F.J., 1987. Dynamics of translithospheric migration of metasomatic fluid and alkaline mamga. In: Menzies, M.A., Hawkesworth, C.J. (Eds.), Mantle metasomatism. Academic Press, London, pp. 1-18.

Spicer, R.A., Harris, N.B.W., Widdowsone, M., Herman, A.B., Guo, S.X., Valdes, P.J., Wolfe, J.A., Kelley, S., 2003. Constant elevation of southern Tibet over the past 15 million years. Nature 421, 622-624.

Steiger, R.H., Jäger, E., 1977. Convention on the use of decay constants in geo- and cosmochronology. Earth and Planetary Science Letters 36, 359-362.

St-Onge, M.R., Searle, M.P., Wodicka, N., 2006. Trans-Hudson orogen of North America and Himalaya-Karakoram-Tibetan orogen of Asia: Structural and thermal characteristics of the lower and upper plates. Tectonics 25, TC4006. doi:10.1029/2005TC001907.

Turner, S., Arnaud, N., Liu, J., Rogers, N., Hawkesworth, C., Harris, N., Kelley, S., Van Calsteren, P., Deng, W., 1996. Post-collision, shoshonitic volcanism on the Tibetan Plateau; implications for convective thinning of the lithosphere and the source of ocean island basalts. Journal of Petrology 37, 45-71.

Turner, S., Hawkesworth, C., Liu, J., Rogers, N., Kelley, S., van Calsteren, P., 1993. Timing of Tibetan uplift constrained by analysis of volcanic rocks. Nature 364, 50-54.

Wang, Q., McDermott, F., Xu, J.F., Bellon, H., Zhu, Y.T., 2005. Cenozoic K-rich adakitic volcanic rocks in the Hohxil area, northern Tibet: Lower-crustal melting in an intracontinental setting. Geology 33, 465-468.

Watts, D.R., Harris, N.B.W.The Nasa Glenn Soars Working Group, 2005. Mapping granite and gneiss in domes along the North Himalayan antiform with ASTER SWIR band ratios. Geological Society of America Bulletin 117, 879-886.

Williams, H., Turner, S., Kelley, S., Harris, N., 2001. Age and composition of dikes in Southern Tibet: New constraints on the timing of east-west extension and its relationship to postcollisional volcanism. Geology 29, 339-342.

Williams, H.M., Turner, S.P., Pearce, J.A., Kelley, S.P., Harris, N.B.W., 2004. Nature of the source regions for post-collisional, potassic magmatism in southern and northern Tibet from geochemical variations and inverse trace element modelling. Journal of Petrology 45, 555-607.

Yin, A., Harrison, T.M., Murphy, M.A., Grove, M., Nie, S., Ryerson, F.J., Wang, X., Chen, Z., 1999. Tertiary deformation history of southeastern and southwestern Tibet during the Indo-Asian collision. Geological Society of America Bulletin 111, 1644-1664.

Yin, A., Harrison, T.M., Ryerson, F.J., Chen, W.J., Kidd, W.S.F., Copeland, P., 1994 Tertiary structural evolution of the Gangdese thrust system in southeastern Tibet. Journal of Geophysical Research 99, 18175-18201. 